\title{
EFFECT OF KAP SUBSTITUTION AND ANNUAL REPORT DISCLOSURE ON MARKET REACTIONS
}

\author{
Nita Nurul Fajar, Listiya Ike Purnomo \\ Universitas Pamulang \\ listiyaike81@gmail.com
}

\begin{abstract}
The purpose of this study is to find out how much the market reaction is influenced by the substitution of KAP and disclosure of annual reports in a given period. Abnormal Return is used as a measurement for market reactions while the variables used in this study are Substitution of KAP and mandatory disclosures used to measure disclosure of annual reports. The data use form of audited financial statements by an independent auditor obtained from the official IDX website www.idx.com using a purposive sampling method based on certain criteria. Samples in this study were 16 manufacturing companies listed on the Indonesia Stock Exchange in 2012-2016. So that the total sample obtained is 80 company data. Hypothesis testing is done by using multiple linear regression data analysis techniques. Data is collected, then processed and analyzed using the SPSS 22.0 for Windows application program. The results of this study are Substitution of KAP had a significant effect while the disclosure of the annual report had no effect, but the two variables simultaneously had an effect on the market reaction.
\end{abstract}

Keywords: Market Reaction, KAP Substitution, Annual Report Disclosure

\section{INTRODUCTION}

Companies are required to be more transparent in providing financial and performance reports company management. One of the information that is considered relevant by investors is published financial statements.

Financial statements provide various information needed by both internal and external parties such as shareholders, creditors, investors and other users of financial statements for investment decision making. And one way to monitor the performance of companies going public is by looking at published financial statements. So that investors are sure of the financial statements presented the true state of the company and are free from material misstatement, a financial statement inspection service is needed by an independent and competent third party, namely the Public Accounting Firm (KAP).

KAP is a form of organization of public accountants who have obtained permits in accordance with the Law that provides professional services in the practice of public accountants (Mulyadi, 2009).

Apart from the replacement of KAP, other factors that influence market reaction, can be obtained by disclosing mandatory disclosure that will be used by users of annual financial statements. Mandatory disclosures are disclosures required in annual reports according to Bapepam regulations. The phenomenon of increased disclosure of financial 
reporting is based on the importance of the role of disclosure for users of financial statement decisions. Publication of financial statements, especially the balance sheet and profit and loss is important information for investors because both information can show how healthy the company is.

Changes in stock prices that are reflected can produce positive or negative market reactions due to changes in KAP and disclosure of company annual reports. With the information on KAP changes determined by the Minister of Finance and the complete submission of annual reports by Bapepam, researchers become interested if the replacement of KAP and disclosure of annual reports are related to market reactions.

The problem formulation in this study is as follows:

a. Are there influences between KAP changes and disclosure of annual reports on market reactions?

b. Is there an influence between KAP turnover and market reaction?

c. Is there an influence between disclosure of annual reports on market reactions?

\section{LITERATURE REVIEW}

\subsection{Stakeholder Theory}

Stakeholder theory according to Freeman and Reed (Ulum, 2009) is a group of people or individuals identified as influencing company activities or influenced by company activities, therefore the corporation must take into account all the interests and values of its stakeholders.

\subsection{Signaling Theory}

Information published as an announcement will provide a signal for investors in making investment decisions (Hartono, 2008). With this signal theory investors will be easier to make investment decisions. In some studies, signal theory testing aims to see the extent of the information content held by an announcement disclosed by the company (Handoko, 2014).

Some announcements that are usually used in testing this theory include announcements relating to profits, dividend announcements, announcements regarding funding and investment, announcements relating to government policies, announcements regarding employment, announcements relating to law and production, marketing and sales activities, announcements from management and directors to announcements relating to the securities industry (Hartono, 2008)

\subsection{Substitution of KAP}

In the decision of the Minister of Finance No.423 / KMK.06 / 2002 and updated KMK No.359 / KMK.06 / 2003 which was later revised with the Regulation of the Minister of Finance No.17 / PMK.01 / 2008 concerning Public Accountant Services regarding restrictions on the period of service provision audit by the Public Accountant Office (KAP) for a maximum of 6 consecutive financial years and a Public Accountant (AP) for a maximum of 3 consecutive years.

\subsection{Mandatory Disclosure}

Mandatory disclosures are minimum disclosures required by applicable regulations. Regulations concerning information disclosure standards for companies that have conducted public offerings and public companies, namely, Regulation No. VIII.G.7 concerning Guidelines for Presentation of Financial Statements and Regulations No. VIII.G.2 concerning the Annual Report. The regulation was updated with Circular No. Bapepam Chairman. SE-02 / PM / 2002 which regulates the presentation and disclosure of financial statements of issuers or 
public companies for each type of industry.

\subsection{Market Reactions}

\subsubsection{Stock Returns}

According to Jogiyanto (2009), stock returns can be divided into two, namely return realization and expected return.

\subsubsection{Return Realization}

Return realization is a return that occurs at that time which is the difference from the current price with the previous price (based on historical data). Return realization is important because it is used as a measure of company performance. This historical return is also useful as a basis for determining the expected return and future risks.

\subsubsection{Return Expectations}

The expected return is the return used for investment decision making. This return is important compared to the historical return because the expected return is the expected return from the investment that will be made (Jogiyanto, 2003).

Expectation return is the expected return on an investment that will be received in the future. The calculation of expected returns is done with a marketadjusted model (market adjusted model), by assuming that the best estimator for estimating securities returns is the market index return at that time (Jogiyanto, 2003).

\subsubsection{Abnormal Return}

According to Jogiyanto (2003), returns are the results obtained from investment. Return can be in the form of a return that is a return that has occurred which is calculated based on historical data, and an expected return that is a return that is expected to occur in the future which is calculated by multiplying each future result with the probability of occurrence and summing it up.

\subsection{Development of Hypotheses}

$\mathrm{H} 1$ : It is suspected that there is an influence between the replacement of H2: KAP Substitution has an influence on market reactions

H3: Annual Report Disclosures have an influence on Market Reactions

\section{RESEARCH METHOD}

\subsection{Data Collection Techniques}

Data collection is done by documentation techniques. The type of data used is secondary data is research data obtained indirectly through intermediary media in the form of documentary data such as books, records or historical reports.

\subsection{Operational Definitions of} Variables

3.2.1. Substitution of KAP

Variable replacement of the Public Accountant Office is measured using dummy variables. If the company makes a KAP change then it will be given a value of 1 and in addition it will be given a value of 0 .

3.2.2. Annual Report Disclosure

Mandatory disclosure is a minimum mandatory disclosure that is implied by applicable regulations. The level of disclosure must be indicated using the mandatory disclosure index.

According to Zaki et al (2011) the calculation of the index is done by the formula:

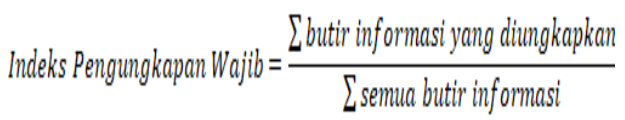

Where :

Score 1 if the information item is revealed

A score of 0 if the information item is not revealed 


\subsubsection{Market Reactions (Abnormal Return)}

Calculation of the return used is the annual return. The several stages to get Abnormal Return, namely:

The first step is to look for actual returns or real returns. The formula for calculating the actual return, namely:

$$
\text { Rit }=\frac{\text { Pit }-P_{i t}-1}{\text { Pit }-1}
$$

Where :

Rit $=$ Return of company stock $\mathrm{i}$ in $\mathrm{t}$ period

Pit $=$ Stock price (closing) of company $\mathrm{i}$ in $t$ period

Pit-1 = Stock price $\mathrm{i}$ in the previous period

The second step is to find the expected return or return, using the market adjusted model equation. The formula for the expected return, namely:

$$
\text { RMt }=\frac{\text { IHSGit }- \text { IHSGit }-1}{\text { IHSGit }-1}
$$

Where :

$\mathrm{RMt}=$ Market return in t period IHSGit $=$ Joint stock price index in $\mathrm{t}$ period

IHSGit-1 = Joint stock price index in period t-1 (previously)

The final stage, namely looking for abnormal returns, the difference between the actual profit and the expected level of profit. The formula for calculating abnormal returns, namely:

\section{ARit $=$ Rit $-E($ Rit $)$}

Where :

ARIT $=$ Abnormal company return $\mathrm{i}$ in $\mathrm{t}$ period

Rit $=$ Actual return that occurs in company $i$ in $t$ period

$\mathrm{E}$ (Rit) $=$ Expected return of company $\mathrm{i}$ in $t$ period

\subsection{Sample Collection Techniques}

The sample selection methode used is purposive sampling. Purposive sampling is the selection of samples based on criteria. The criteria for the researsh sample are as follows:

a. Manufacturing companies listed on the Indonesia Stock Exchange during the study period, namely 2012-2016 with the 2011 base year.

b. Companies that issue audit reports during the 2012-2016 period with the 2011 base year.

c. Companies that consistently have positive net income during the 20122016 period.

d. Companies that have stock closing price data for 2012-2106 with 2011 base year.

e. The company publishes financial statements using the rupiah currency

\subsection{Data Analysis Techniques}

In analyzing and processing research data using SPSS 22 software. To answer the formulation of research problems and obtain empirical evidence from hypotheses that have been made, the analytical techniques carried out include:

1. Descriptive statistics

2. Normality Test, Non Heterocedasticity, Non Autocorrelation and Non Multicollinearity

3. Multiple Linear Regression Analysis

4. Coefficient of Determination

5. Feasible of the regresion model-test (F test)

6. Individual intrument test ( $\mathrm{t}$ test) 


\section{RESULTS AND DISCUSSION}

\subsection{Result}

In this study manufacturing companies were chosen because this type of company has quite a large number of companies so that it is expected to represent the entire company contained in the Indonesia Stock Exchange. The main characteristic of manufacturing industry activities is processing resources into finished goods through a manufacturing process. Therefore, the activities of companies belonging to the manufacturing industry group have at least three main activities, namely:

a. Activities to obtain or store inputs or raw materials

b. Processing / manufacturing / assembly activities of raw materials into finished goods

c. Activities to store or market finished goods of knowledge.

\subsubsection{Descriptive Statistics Test}

Descriptive statistics will describe the description of each variable. The table that describes of all variables in this study includes the minimum, maximum, mean (average) and standard deviation values. The descriptive statistics of the overall sample of the company can be seen in the following table:

Table 1

Descriptive Statistics

\begin{tabular}{|c|c|c|c|c|c|}
\hline & $\mathrm{N}$ & Min & Max & Mean & $\begin{array}{l}\text { Std. } \\
\text { Devia } \\
\text { tion }\end{array}$ \\
\hline $\begin{array}{c}\text { Substitutio } \\
n \\
\text { of KAP }\end{array}$ & 80 & 0 & 1 & .13 & .333 \\
\hline $\begin{array}{l}\text { Mandatory } \\
\text { Disclosure }\end{array}$ & 80 & $\begin{array}{l}.52 \\
9\end{array}$ & $\begin{array}{l}.73 \\
5\end{array}$ & $\begin{array}{c}.6106 \\
4\end{array}$ & .054236 \\
\hline $\begin{array}{l}\text { Abnormal } \\
\text { Return } \\
\text { Valid N } \\
\text { (listwise) }\end{array}$ & 80 & .006 & $\begin{array}{l}.91 \\
8\end{array}$ & $\begin{array}{c}.2250 \\
6\end{array}$ & .182304 \\
\hline
\end{tabular}

\subsubsection{Normality Test}

The results of the normality test in this study can be seen in table 2 as follows:

Table 2

Normality Test

\begin{tabular}{|ll|r|}
\hline & & \multicolumn{2}{|c|}{$\begin{array}{c}\text { Unstandardized } \\
\text { Residual }\end{array}$} \\
\hline \multicolumn{2}{|c|}{$\mathrm{N}$} & 80 \\
Normal & Mean & .0000000 \\
& Std. & \\
& Deviation & .17259254 \\
Most & Absolute & .094 \\
Extreme & Positive & .094 \\
Differences & Negative & -.058 \\
& Test Statistic & .094 \\
Asymp. Sig. (2-tailed) & $.078^{\mathrm{c}}$ \\
\hline
\end{tabular}

a. Test distribution is Normal.

Source: Secondary data processed using SPSS 22

Kolmogorov-Smirnov test shown in the normality test table, the Asymp.Sig (2-tailed) value is 0.078. The requirement to pass the normality test is Asymp. Sig (2-tailed)> 0.05 so that the data in the normality test table above can be said to be normal.

\subsubsection{Non Multicollinearity Test}

The multicollinearity test aims to test whether the regression model found an independent variable correlation of independent variable. The following table shows the results of the multicollinearity test of all variables. 
Table 3

Non Multicollinearity Test Result

\begin{tabular}{|c|c|c|r|}
\hline \multicolumn{2}{|c|}{ Model } & \multicolumn{2}{|c|}{ Collinearity Statistics } \\
\cline { 2 - 4 } & Tolerance & VIF \\
\hline \multirow{2}{*}{1} & (Constant) & & \\
\cline { 2 - 4 } & $\begin{array}{c}\text { Substitution } \\
\text { of KAP }\end{array}$ & .897 & 1.115 \\
\cline { 2 - 4 } & $\begin{array}{c}\text { Annual } \\
\text { Report } \\
\text { Disclosures }\end{array}$ & .897 & 1.115 \\
\hline
\end{tabular}

a. Y : Abnormal Return

VIF values obtained in the table above, the independent variables do not correlate with each other. VIF values obtained from each independent variable are less than 10 and tolerance values are above the value of 0.10 . This shows that there is no correlation between fellow independent variables in the regression model and it can be concluded that there is no multicollinearity problem among fellow independent variables in this regression model.

\subsubsection{Non Heteroscedasticity Test}

Non heteroscedasticity test in this study uses a scatterplot graph. It can be seen that the points spread well above 0 on the $\mathrm{Y}$ axis, there is non heteroscedacity.

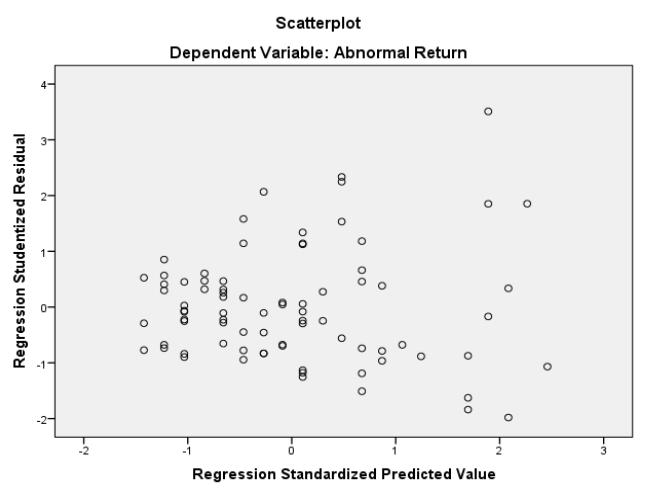

The scatterplot graph can be seen that the points spread well above 0 on the $\mathrm{Y}$ axis. It can be concluded that there is non heteroscedacity in this regression model.

\subsubsection{Non Autocorrelation Test}

The autocorrelation test in the study used the Durbin-Watson (DW). Regression models that did not occur autocorrelation if the value of $\mathrm{du}<\mathrm{d}<4$ $\mathrm{du}$ (Ghozali, 2011: 111). The results of the autocorelation test in this study can be seen in table 4.4 as follows:

Table 4

Non Autocorrelation Test Results

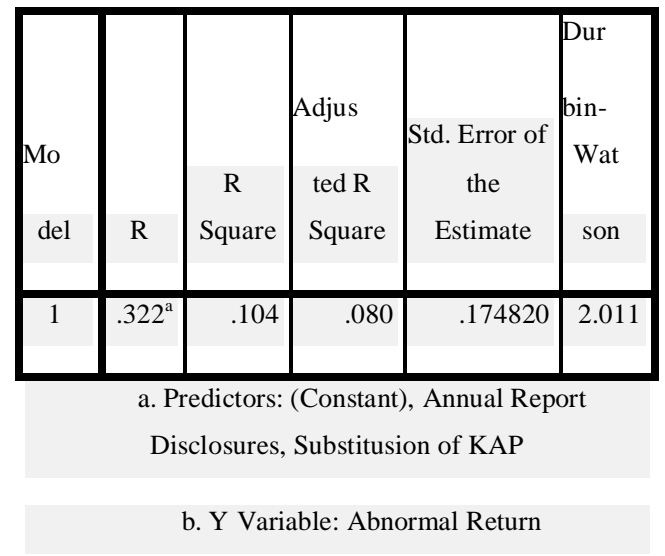

The autocorrelation test results in the table above show that the DurbinWaston value (d) is 2.011. This value will be compared with the value in the Durbin-Waston table using a significance of $5 \%$ and the number of observations (n) 80 and the number of independent variables $2(\mathrm{~K}=2)$.

Based on the Durbin-Watson table, the upper limit $(\mathrm{du})$ value is 1.6851 . The way to determine du is, $(\mathrm{n}-\mathrm{K})$ or $(80-2=$ 78) so that the equation is obtained as follows:

$\mathrm{du}<\mathrm{d}<4=$ du $1,6851<2,011<2,3149$

Then it can be concluded that in this research regression model there is no positive or negative autocorrelation. 


\subsubsection{Multiple Linear Regression Tests}

Regression analysis that explains the relationship between the dependent and independent variables is closely related to statistical relationships, not definite relationships. Based on output SPSS version 22 , the following calculations are obtained:

Table 5

Multiple Linear Regression Test Results

\begin{tabular}{|c|c|c|c|}
\hline \multicolumn{2}{|c|}{ Model } & \multicolumn{2}{c|}{$\begin{array}{c}\text { Unstandardized } \\
\text { Coefficients }\end{array}$} \\
\cline { 3 - 4 } & \multicolumn{1}{|c|}{} & $\beta$ & $\begin{array}{c}\text { Standar } \\
\text { Error }\end{array}$ \\
\hline \multirow{2}{*}{1} & (Constant) & .260 & .237 \\
\cline { 2 - 4 } & Substitution of KAP & .172 & .062 \\
\cline { 2 - 4 } & $\begin{array}{c}\text { Annual Report } \\
\text { Disclosures }\end{array}$ & .760 & .383 \\
\hline
\end{tabular}

a. Y Variable: Abnormal Return

Source: output SPSS 22

The results of the regression analysis produce the following equation:

$\mathrm{Y}=\mathrm{a}+\mathrm{b} 1 \mathrm{X} 1+\mathrm{b} 2 \mathrm{X} 2+\mathrm{e}$

$\mathrm{Y}=0,260+0,172 \mathrm{X} 1+0,760 \mathrm{X} 2+0,237$

Where:

$\mathrm{Y}=$ Market Reaction

$\mathrm{a}=$ Constant

$\mathrm{X} 1=$ Substitution of KAP

$\mathrm{X} 2$ = Annual Report Disclosures

$\mathrm{e}=$ error

\subsubsection{Feasible of the Regression Model Test (F Test)}

Feasible of the Regression Model test can be seen in the following table:
Table 6

ANOVA

\begin{tabular}{|l|c|c|c|c|c|}
\hline $\begin{array}{l}\text { Mode } \\
1\end{array}$ & $\begin{array}{c}\text { Sum } \\
\text { of } \\
\text { Squar } \\
\text { e }\end{array}$ & df & $\begin{array}{l}\text { Mean } \\
\text { Square }\end{array}$ & F & Sig. \\
\hline $\begin{array}{l}\text { Regres } \\
\text { Sion } \\
\text { Residu } \\
\text { al }\end{array}$ & .272 & 2 & .136 & 4.454 & $\begin{array}{r}.01 \\
5^{b}\end{array}$ \\
Total & 2.353 & 77 & .031 & & \\
\hline \multicolumn{5}{c}{ a. Y Variable: Abnormal Return } \\
b. X: (Constant), Annual Report \\
Disclosures, Substitution of KAP
\end{tabular}

Source: output SPSS 22

The table above shows that a significance level of $0.015<0.05$. This meaning the change of KAP and disclosure Annual reports simultaneously have an influence on market reactions. These results also show that multiple linear regression models are feasible to be used as a measurement or measurement tool.

\subsubsection{Test for Individual Parameters (t Test)}

The $t$ test aims to determine whether there is an influence of each independent variable, where the turnover of KAP (X1), and annual report disclosure (X2) to market reaction.

Tabel 7

t-Test Result

\begin{tabular}{|l|l|l|l|}
\hline \multicolumn{2}{|c|}{ Model } & \multicolumn{1}{c|}{$\mathrm{t}$} & \multicolumn{1}{c|}{ Sig. } \\
\hline \multirow{2}{*}{1} & (Constant) & 1.097 & .276 \\
\cline { 2 - 4 } & $\begin{array}{l}\text { Pergantian } \\
\text { KAP }\end{array}$ & 2.750 & .007 \\
\cline { 2 - 4 } & $\begin{array}{l}\text { Pengungkapa } \\
\text { n Wajib }\end{array}$ & 1.984 & .051 \\
\hline
\end{tabular}

a. Y Variable: Abnormal Return

Source: output SPSS 22 
The table above it is known that the turnover of KAP shows a significant level of 0.007 which means that it is less than the acceptable error rate of $5 \%$ or $0.05(0.007<0.05)$. Judging from the significance level, this means that the replacement of KAP is statistically influential on the market reaction.

The results show that the disclosure of annual reports shows a significant level of 0.051 which means that it is more than the error rate is $5 \%$ or 0.05 $(0.051>0.05)$. Judging from significance level, this means that the disclosure of annual reports does not affect the market reaction.

\subsubsection{Determination Coefficient} (Adjusted $\mathrm{R}^{2}$ )

The coefficient of determination to measure how far the ability of the regression model to explain dependent variation. the coefficient of determination (Adjusted $\mathrm{R}^{2}$ ) is used to measure how much the independent variable (turnover of KAP and disclosure of annual reports) simultaneously influences changes in the dependent variable (market reaction).

Table 8

Determination Coefficient

\begin{tabular}{|c|c|c|c|c|}
\hline Model & $\mathrm{R}$ & R Square & $\begin{array}{l}\text { Adjusted R } \\
\text { Square }\end{array}$ & $\begin{array}{c}\text { Std. Error } \\
\text { of the } \\
\text { Estimate }\end{array}$ \\
\hline 1 & $.322^{\mathrm{a}}$ & .104 & .080 & .174820 \\
\hline \multicolumn{5}{|c|}{$\begin{array}{l}\text { a. X: (Constant), Annual Report Disclosures, Substitution of } \\
\text { KAP }\end{array}$} \\
\hline
\end{tabular}

bY Variable: Abnormal Return

Source: Secondary data processed using SPSS 22

The results of Adjusted $\mathrm{R}$ Square shows that $8 \%$ market reaction affected by changes in KAP and disclosure of annual reports. The results of the market reaction were $8 \%$ and the rest were influenced by other factors of $92 \%$.

\subsection{Discussion}

4.2.1 Effect of KAP Substitution and Annual Report Disclosure on Market Reactions

Both are closely related because financial statements provide a variety of information needed in decision making by both external and internal parties and to convince stakeholders that financial statements are free of material misstatements needed by financial auditors by KAP. This will signal to investors in making investment decisions.

4.2.2 Effect of KAP Substitution on Market Reactions

Substitution of KAP that is measured using a dummy variable successfully proves that when a company makes an announcement on the replacement of KAP it will show a market reaction both positive and negative. This is reinforced by the existence of a signal theory which explains that any information published as an announcement will strengthen the market response.

Substitution of KAP has a significant effect on market reaction. This result is in line with the research conducted by Fajrina (2013), Handoko (2014) and Putra and Yosefa (2015).

\subsubsection{Effects of Annual Report} Disclosures on Market Reactions

Disclosure of annual reports did not affect the market reaction. Mandatory disclosure measured using a disclosure index proves that investors do not see the amount (quantity) of information disclosed in annual reports but look at the quality of information contained, such as financial statements that are free from material misstatement, consistency of profit generated, dividend distribution, ability companies in paying debts and considering the characteristics of the company itself.

The annual report disclosure does not affect the market reaction. This result is in line with the research conducted by 
Margani, Hijroh and Uswatun (2013), and Yuni and Nyoman (2015).

\section{CONCLUSION}

1. Substitution of KAP successfully proves that when the company makes an announcement on the replacement of KAP the market will show a reaction, both positive and negative.

2. Mandatory disclosures fail to prove the existence of market reactions when the company discloses information contained in the annual

\section{REFERENCES}

Ayu, Maristiana. (2012). Effect of Information Quality Disclosure on Stock Trading Volume and Stock Returns (Empirical Study on LQ45 Companies on the IDX). Lecturer at the Faculty of Economics, Sang Bumi University Ruwa Jurai. Bnadar Lampung.

Banda, Putra and Yosefa Sayekti. (2015). Analysis of Market Reactions to Substitution of Public Accounting Firms and Audit Opinions (Empirical Study on LQ45 Companies in 2012-2014). Student Scientific Article Jember University.

Diaz, Marsela, (2009). Analysis of Market Reactions to Substitution Announcements of Public Accountants (Studies in public companies in Indonesia). Thesis, Master of Accounting, Universitas Brawijaya.

Fajrina, Goesti Nahru. (2014). Effects of Substitution of Public Accounting Firms and Audit Opinions on Market Reactions (Study of Manufacturing Companies Listed on the Stock Exchange for the 2009-2012 Period). Essay. report. Investors do not see the amount (quantity) of information disclosed in annual reports, but stakeholders see from the profits generated, dividend distribution and consider the characteristics of the company itself.

3. Substitution of KAP and disclosure of annual reports successfully prove the existence of market reactions caused by the information items published will provide benefits to stakeholders.
Bachelor of Accounting, Islamic University of Sultan Ageng. Semarang.

Handoko, Sony Cokro, (2014). Substitution Analysis of Public Accountants' Office and Timeliness in Submitting Financial Reports to Market Reactions (Empirical Study on IDX 2009-2012 Period). Thesis, Bachelor of Economics, Diponegoro University.

Decree of the Minister of Finance of the Republic of Indonesia. (2002). About Public Accountant Services No. 423 / KMK.06 / 2002, Jakarta.

Mulyadi. 2009. Salemba Empat Accounting System. Jakarta.

Ngaijan. (2011). Analysis of the Effects of Substitution of Public Accountant Offices and Audit Opinions on Market Reactions. Saintek Maritim Journal, Vol. XVI No. March 2, 2017. Semarang.

Regulation of the Minister of Finance of the Republic of Indonesia. (2008). About Public Accountant Service No. 17 / PMK.01 / 2008, Jakarta.

Financial Services Authority Regulation. (2016). About the Annual Report 
Number 29 / POJK.04 / 2016, Jakarta.

Government Regulation of the Republic of Indonesia. (2015). About the Practice of Public Accountants No. 20 of 2015, Jakarta.

Scott, W.R. (2009). Financial Accounting Theory. Fifth Edition. Toronto: Pearson Prentice Hall.

Sofiana, Nina. (2010). Analysis of the Effect of Company Characteristics on Completeness of Disclosures in the Annual Report of Manufacturing Companies Listed on the IDX. Essay. Muhammadiyah Surakarta university. Surakarta.

Ulum, Ihyaul. (2009). Intellectual Capital: Concepts and Empirical Studies. Graha Ilmu, Yogyakarta
Vahini, Yuni Prema and Nyoman Wijan Asmara Putra. 2014. Event Study: Analysis of Investor Reactions on Publication of Annual Financial Reports. Udayana University Accountancy E-Journal Vol. 13 No. Nov. 2, 2015 (pp. 387-404). Bali.

Veronica, Emilia Mega. (2015). Effect of Substitution of Public Accountant Offices on Market Reactions (Empirical Study on Manufacturing Companies 20102014). Essay. Perbanas College of Economics. Surabaya

Warsono, S. (2010). Accounting Reform: Dismantling Bounded Rationality in Accounting Development. Asgard Chapter. 